\title{
DETERMINATION OF CARBOHYDRATES IN AGRIMONIA EUPATORIA L. HERB
}

\author{
N. Huzio, A. Grytsyk, L. Slobodianiuk
}

\begin{abstract}
In recent years, methods of treatment using medicinal plants and biologically active substances based on them have become increasingly common. Today, the search for plants with a long history of use and minor side effects is of interest to our society. The most promising for procurement and use in medical practice is a common throughout Ukraine - common agrimony (Agrimonia eupatoria L.). The presence of tannins, which are represented by two groups: condensed and hydrolyzed tannins is indicated. There is insufficient information in the literature on the biologically active substances of Agrimonia eupatoria L. The common agrimony herb contains 1.2-1.6\% of flavonoids, which belong to different subgroups. Thus, from the group of flavones apigenin, luteolin, luteolin-7-glycoside have been identified. The herb of Agrimonia eupatoria L. as an insufficiently studied plant raw material is also a promising object of study, including carbohydrate composition.
\end{abstract}

The aim. The aim of our study was to determine the content of carbohydrates in aerial parts of Agrimonia eupatoria L. collected from natural habitat.

Materials and methods. The determination of carbohydrates of Agrimonia eupatoria L. was carried out by gas chromatograph Agilent 6890N with a mass detector 5973 inert (Agilent Technologies, USA). The amounts of water-soluble polysaccharides and pectin substances were determined by gravimetric method.

Results. Three free carbohydrates were found in the studied grass of the Agrimonia eupatoria L., namely: Dglucose, D-galactose and D-fructose, the content of which was $15.02 \mathrm{mg} / \mathrm{g}, 0.28 \mathrm{mg} / \mathrm{g}$ and $12.90 \mathrm{mg} / \mathrm{g}$, respectively. In the common agrimony, after acidic hydrolysis and derivatization with acetylated aldononitriles were identified 8 compounds. The predominant ones were D-glucose, D-galactose and D-xylose. The content of watersoluble polysaccharides and pectin substances in Agrimonia eupatoria L. was determined at $2.90 \%$ and $8.54 \%$ of total dry weight, respectively.

Conclusions. In completion, the present results of GC/MS indicated the presence of certain carbohydrates both in free and bound form in Agrimonia eupatoria L., that have important medicinal activity, which answered to the knowledge about the therapeutic activity of this analyzed plant. We established that in Agrimonia eupatoria L. herb the predominant monosaccharide compound was D-glucose: $23.88 \mathrm{mg} / \mathrm{g}$ and $15.02 \mathrm{mg} / \mathrm{g}$ among monosaccharides after hydrolysis and free monosaccharides respectively. Our findings propose that carbohydrates from the studied raw material can be used for creating drugs by the pharmaceutical industry, and could be used for the development of nutraceuticals

Keywords: Agrimonia eupatoria L., carbohydrates, GC/MS, water-soluble polysaccharides, pectin substances, gravimetric method

Copyright (C) 2020, N. Huzio, A. Grytsyk, L. Slobodianiuk.

This is an open access article under the CC BY license (http://creativecommons.org/licenses/by/4.0).

\section{Introduction}

In recent years, methods of treatment using medicinal plants and biologically active substances based on them have become increasingly common. Today, the search for plants with a long history of use and minor side effects is of interest to our society [1]. Plants of the genus Agrimonia L. of the family Rosaceae, which have long been used in medicine in many countries as antiinflammatory, hepatoprotective, choleretic, diuretic, anthelmintic and antispasmodic agents, are promising objects for phytochemical study [2-5].

The most promising for procurement and use in medical practice is a common throughout Ukraine common agrimony (Agrimonia eupatoria L.), which contains a large number of different biologically active substances. Ukrainian scientists H. S. Naprasnikova and others by the method of absorption spectrophotometry have determined the content of tannins, which are represented by two groups: condensed and hydrolysable tannins. Ellagic acid and agrimoniin are present among the hydrolyzed tannins [6]. Agrimonia eupatoria L. herb also contains $1.2-1.6 \%$ of flavonoids, which belong to different subgroups. Thus, from the group of flavones apigenin, luteolin, luteolin-7-glycoside have been identified [7]. Also Kato $\mathrm{H}$. et al. have identified the following flavonoids in the herb of the common agrimony: luteolin 7-O-sophosroside, luteolin 7-O-(6"-acetylglucoside), acacetin 7-O-glucoside, luteolin 7-O-glucoside and apigenin 7-O-glucoside [8, 9]. Investigating the herb of the common agrimony, Kozak I. V. et al. showed that when quantifying the amount of flavonoids, the conversion should be carried out on luteolin or luteolin-7-Oglucoside and that the identification markers of the common agrimony herb selected rutin, hyperoside, isoquercitrin [10].

The mechanism of anti-inflammatory action of biologically active substances of the common agrimony has been proved by scientists Correia H. S. et al. They have substantiated the association between the antiinflammatory activity of Agrimonia eupatoria L. wateralcohol extracts and the presence of polyphenolic compounds in the plant [2]. 
It is also known that the herb of Agrimonia eupatoria L. accumulates substances of primary synthesis - carbohydrates [11]. The study of the content and qualitative composition of carbohydrates of the herb Agrimonia eupatoria L. is expedient due to the fact that carbohydrates, in addition to important functional significance and specific pharmacological activity, also influence the development of the total pharmacological effect of plant-derived drugs. The herb of $\mathrm{Ag}$ rimonia eupatoria $\mathrm{L}$. as an insufficiently studied plant raw material is also a promising object of study, including carbohydrate composition.

Thus, the aim of our study was to determine the content and qualitative composition of carbohydrates in aerial parts of Agrimonia eupatoria L. collected from natural habitat.

\section{Planning (methodology) of research.}

To achieve this aim and get answers to all questions, the design of the experiment was done (Fig. 1).

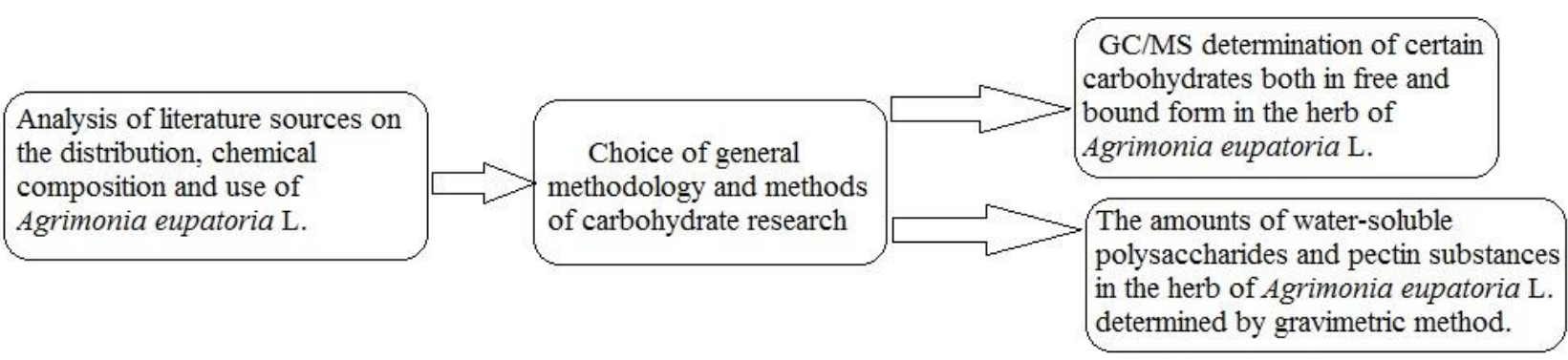

Fig. 1. Design of the experiment

\section{Material and method}

\subsection{Plant materials}

Agrimonia eupatoria L. herb was chosen as the object of study. The aboveground part of the studied plant was collected in Western Ukraine, at the territory of Vovchynets, Ivano-Frankivsk region (N 48 $57^{\prime} 06^{\prime \prime} \mathrm{N}$ $24^{\circ} 44^{\prime} 46^{\prime \prime} \mathrm{E}$ ) during the flowering period in 2017.

The raw material was authenticated by assoc. prof. Hanna Nedostup (IFNMU, Ivano-Frankivsk, Ukraine).

\subsection{Chemicals and standards}

The conventional methods for quantification of carbohydrates and determining their monomeric content were used: gas chromatography with mass spectrometry (GC/MS) and gravimetry. Standard reagents including Lrhamnose, D-mannose, D-ribose, D-xylose, D-arabinose, Dgalactose D-fucose, D-glucose, D-fructose, D-saccharo-se, and D-sorbitol were obtained from Sigma-Aldrich Chemical Co. ( $\geq 99 \%$ purity) (Fig. 2). All solvents for metabolite extraction were of analytical grade ( $>95 \%$ purity).

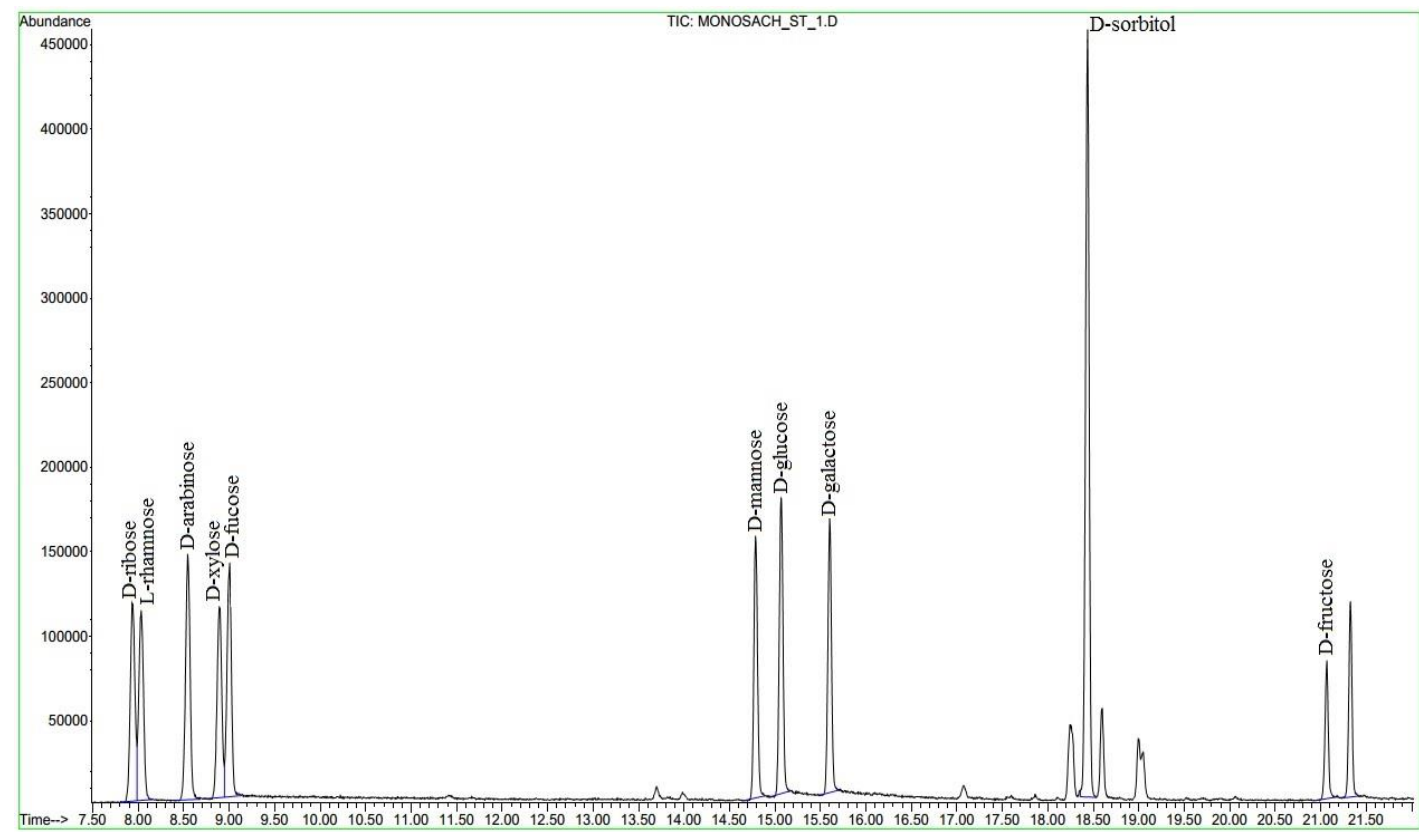

Fig. 2. GC/MS chromatogram of sugars standards

\subsection{Determination of carbohydrates}

The monosaccharides composition of Agrimonia eupatoria L. herb was determined by GC/MS method on gas chromatograph Agilent 6890N with 5973inert mass detector (Agilent Technologies, USA). Samples were analyzed on a capillary column HP-5MS of $30 \mathrm{~m}$ in length and an internal diameter of $0.25 \mathrm{~mm}$, a thickness of the stationary phase is $0.25 \mu \mathrm{m}$. Firstly, we set up oven temperature at $160^{\circ} \mathrm{C}$ and held for $8 \mathrm{~min}$, then raised to $240{ }^{\circ} \mathrm{C}$ at the rate of $5{ }^{\circ} \mathrm{C} / \mathrm{min}$ and kept at this point for 
$6 \mathrm{~min}$. At a constant flow rate of $1.2 \mathrm{sm}^{3} / \mathrm{min}$ was used helium as the carrier gas. Detection was performed in the SCAN mode at the width range of $38-400 \mathrm{~m} / \mathrm{z}$.

Extraction of free monosaccharides. $0.5 \mathrm{mg}$ of methanol solution with internal standard (sorbitol) was added to $500 \mathrm{mg}$ of powdered raw materials. The extraction was performed at the ultrasonic water bath at $80{ }^{\circ} \mathrm{C}$ for 4 hours.

Extraction and hydrolysis of bonded monosaccharides. For the extraction of bonded monosaccharides or monosaccharides after hydrolysis $500 \mathrm{mg}$ of powdered herb of the raw material was placed into the flask and added $5 \mathrm{ml}$ of $2 \mathrm{M}$ trifluoroacetic acid. Hydrolysis was performed under $100{ }^{\circ} \mathrm{C}$ for 6 hours. $2 \mathrm{~mL}$ of obtained hydrolysate was evaporated and was added $2 \mathrm{ml}$ of an internal standard.

To obtain acetylated aldonitriles. $2 \mathrm{ml}$ of the extract was evaporated to dryness and was added $0.3 \mathrm{ml}$ of derivatization reagent $(32 \mathrm{mg} / \mathrm{ml}$ of hydroxylamine hydrochloride in pyridine/methanol $(4: 1, \mathrm{v} / \mathrm{v}))$. The extract was incubated at $75{ }^{\circ} \mathrm{C}$ for $25 \mathrm{~min}$. To the samples was subsequently added $1 \mathrm{~mL}$ of acetic anhydride and incubated at $75{ }^{\circ} \mathrm{C}$ for $15 \mathrm{~min}$. $2 \mathrm{ml}$ of dichloroethane was added and the excess of the derivatization reagents was removed by the double extraction with water and $1 \mathrm{M}$ hydrochloric acid. The dichloroethane layer was dried and dissolved in $300 \mu \mathrm{l}$ of the mixture of ethyl acetate/heptane $(1: 1, \mathrm{v} / \mathrm{v})$.

Identification of monosaccharides was based on comparing their retention times with retention times of standards of the mass spectral library NIST 02. Quantification was done by using sorbitol added to the sample [12-14].

The number of carbohydrates in $\mathrm{mg} / \mathrm{g}$ was calculated according to the following equation:

$$
\mathrm{X}=\frac{\text { Sx } \times \text { Minst } \times 1000}{\text { Sinst } \times m}
$$

where: $S x$ - is a peak area of each monosaccharide or disaccharide; Minst - is a mass of the internal standard; Sinst - is a peak area of the internal standard; $m-$ is a mass of plant material $[12,15]$.

The amounts of water-soluble polysaccharides and pectin substances were determined by gravimetric method reported by Kyslychenko O. A. et al [16]. All samples were analyzed in triplicates and the results were averaged.

\subsection{Statistical analysis}

Statistical processing and data analysis were performed using program package Statistica v 7.0 (Statsoft, USA) for Microsoft Office for Windows - MS Exel 2007. The level of significance was set at ${ }^{*} p<0.05$ for all statistical analyses.

\section{Results}

Gas chromatography coupled with mass spectrometry (GC/MS) was used to identify and measure the carbohydrates content in Agrimonia eupatoria L. herb. Three free sugars were detected in the studied herb of the Agrimonia eupatoria L. included Dglucose, D-galactose and D-fructose, the content of which was $15.02 \mathrm{mg} / \mathrm{g}, 0.28 \mathrm{mg} / \mathrm{g}$ and $12.90 \mathrm{mg} / \mathrm{g}$, respectively (Fig. 3, Table 1).

The results of the study showed that the major components free carbohydrates of the herb of Agrimonia eupatoria L. were D-glucose and D-fructose (Table 1).

In this analyzed material, after acidic hydrolysis and derivatization with acetylated aldononitriles, Drhamnose, L-arabinose, D-xylose, D-mannose, Dglucose, D-galactose, D-mannitol and D-Dulcitol were identified too (Fig. 4, Table 2). The predominant ones were D-glucose $(23.88 \mathrm{mg} / \mathrm{g})$, D-galactose $(9.37 \mathrm{mg} / \mathrm{g})$ and D-xylose $(5.98 \mathrm{mg} / \mathrm{g}$ ) (Table 2$)$.

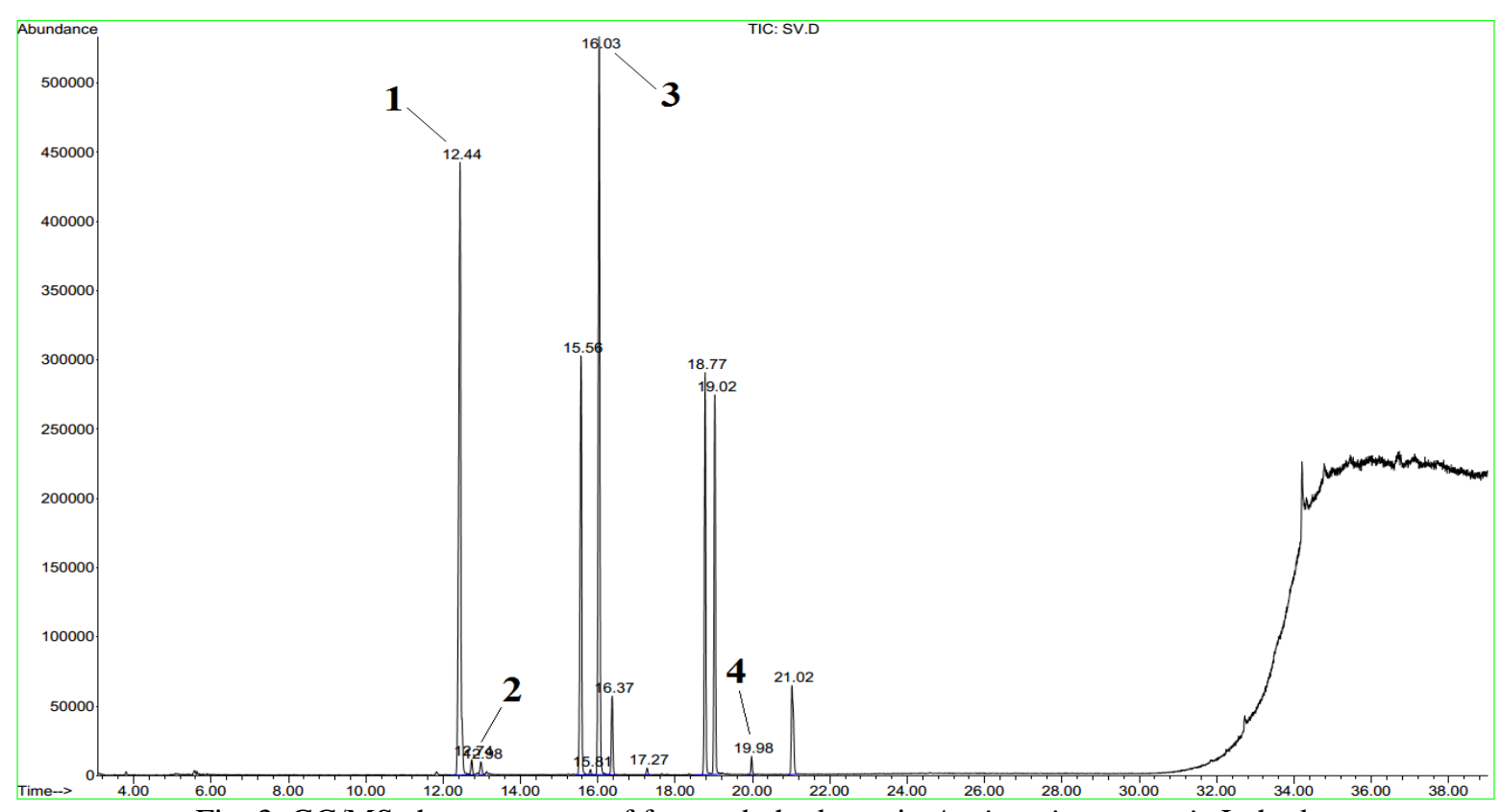

Fig. 3. GC/MS chromatogram of free carbohydrates in Agrimonia eupatoria L. herb 
Table 1

The results of free carbohydrates determination in Agrimonia eupatoria L. herb.

\begin{tabular}{|c|c|c|c|}
\hline $\begin{array}{c}\text { Peak on } \\
\text { chromatogram }\end{array}$ & RT, min & $\begin{array}{c}\text { Content of carbohydrates, (mg/g) } \\
\bar{x} \pm \Delta \bar{x}, \mathrm{n}=3, \mathrm{P}<0.05\end{array}$ & The name of the carbohydrate \\
\hline 1 & 12.387 & $15.02 \pm 0.03$ & D-glucose \\
\hline 2 & 12.9742 & $0.28 \pm 0.01$ & D-galactose \\
\hline 3 & 16.0342 & internal standard & D-sorbitol \\
\hline 4 & 19.7711 & $12.90 \pm 0.02$ & D-fructose \\
\hline
\end{tabular}

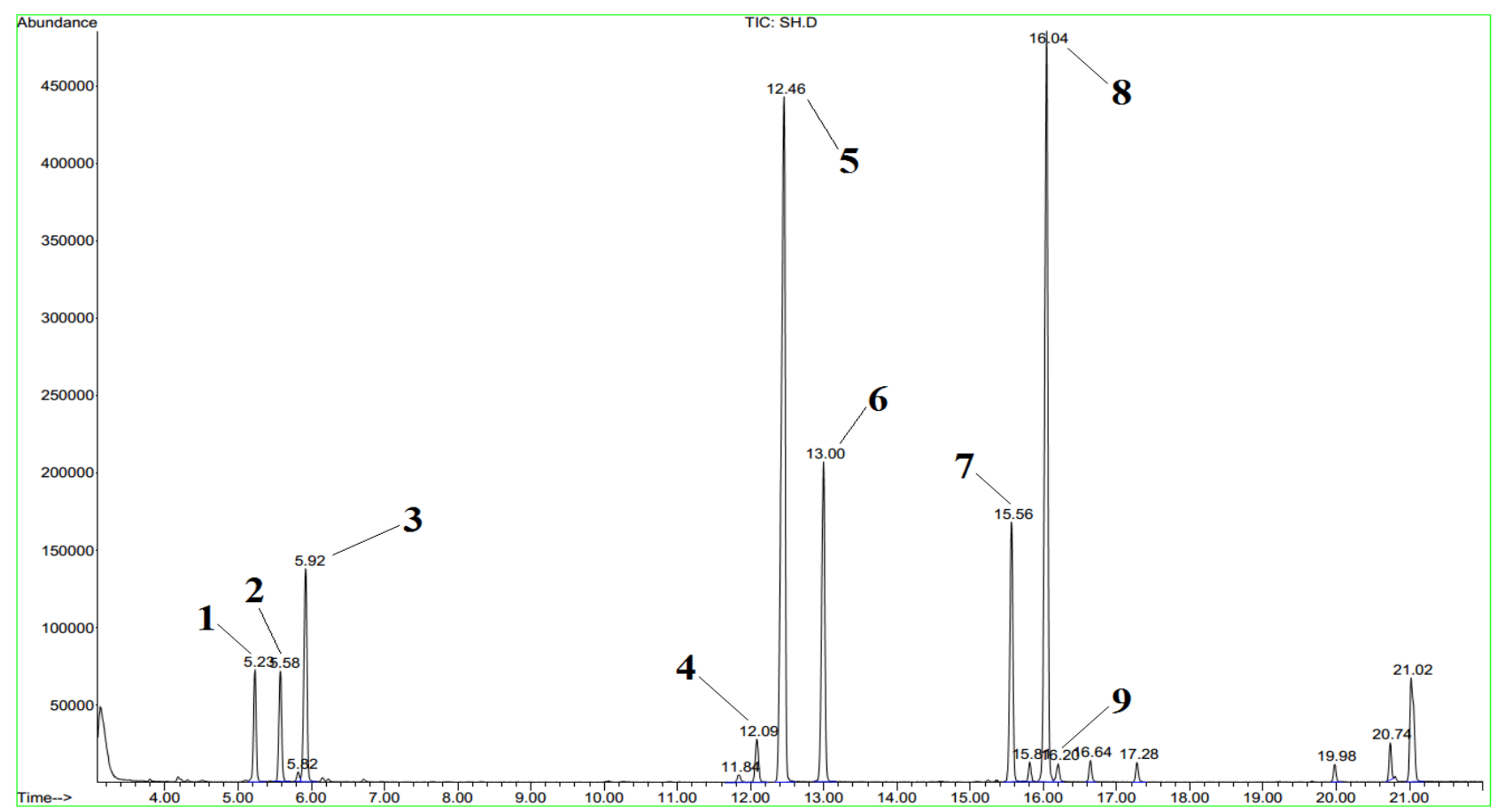

Fig. 4. GC/MS chromatogram of monosaccharides and their derivatives after hydrolysis in Agrimonia eupatoria L. herb

Table 2

The results of monosaccharides and their derivatives after hydrolysis in Agrimonia eupatoria L. herb.

\begin{tabular}{|c|c|c|c|}
\hline $\begin{array}{c}\text { Peak on } \\
\text { chromatogram }\end{array}$ & RT, min & $\begin{array}{c}\text { Content of carbohydrates, (mg/g) } \\
\bar{x} \pm \Delta \bar{x}, \mathrm{n}=3, \mathrm{P}<0.05\end{array}$ & The name of the carbohydrate \\
\hline 1 & 5.2308 & $2.72 \pm 0.03$ & D-rhamnose \\
\hline 2 & 5.5793 & $2.78 \pm 0.02$ & L-arabinose \\
\hline 3 & 5.9236 & $5.98 \pm 0.02$ & D-xylose \\
\hline 4 & 12.086 & $1.32 \pm 0.01$ & D-mannose \\
\hline 5 & 12.4558 & $23.88 \pm 0.02$ & D-glucose \\
\hline 6 & 12.9965 & $9.37 \pm 0.03$ & D-galactose \\
\hline 7 & 15.8133 & $0.49 \pm 0.01$ & D-mannitol \\
\hline 8 & 16.0428 & internal standard & D-sorbitol \\
\hline 9 & 16.2000 & $0.50 \pm 0.01$ & D-Dulcitol \\
\hline
\end{tabular}

The content of water-soluble polysaccharides and pectin substances in Agrimonia eupatoria L. was deter- mined at $2.90 \pm 0.02 \%$ and $8.54 \pm 0.04 \%$ of total dry weight, respectively (Fig. 5). 


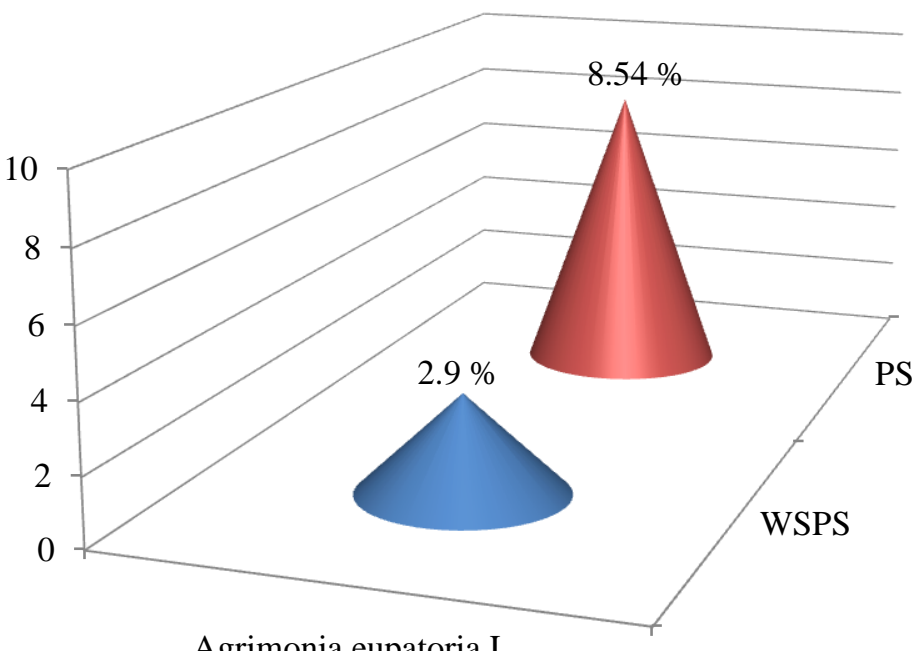

- WSPS

- PS

Fig. 5. Water-soluble polysaccharides (WSPS) and pectin substances (PS) in Agrimonia eupatoria L.

\section{Discussion}

Carbohydrates are energy-rich molecules providing energy for life processes as well as building parts of the cell walls of plants and animals. In animals, they play crucial role in the immune system, pathogenesis, and blood clotting responses. Polysaccharides have sorbent, expectorant, antiulcer, anti-inflammatory, and detoxifying actions [15].

We established that in Agrimonia eupatoria L. herb the predominant monosaccharide compound was Dglucose: $23.88 \mathrm{mg} / \mathrm{g}$ and $15.02 \mathrm{mg} / \mathrm{g}$ among monosaccharides after hydrolysis and free monosaccharides respectively. The basic appointment of this aldohexose is to delivery energy for physiological processes [17]. Of the all mammalian organs and tissues, the brain is highly requiring in terms of energy metabolism. Its functions, such as memory, thinking and cognitive learning, are interlinked to the effective utilization of glucose $[18,19]$. If the concentration this monosaccharide lowery, the processes demanding mental effort are deteriorated [13, 17].

In the herb of the Agrimonia eupatoria L. also predominant ones were D-galactose $9.37 \mathrm{mg} / \mathrm{g}$ and Dxylose $5.98 \mathrm{mg} / \mathrm{g}$. D-galactose is a physiological nutrient that can be combining with glucose and form the disaccharide lactose [20, 21]. D-xylose has antifungal and antibacterial properties, namely is affecting with Candida species and gram-negative organisms. In contradistinction to saccharose, xylose promotes the rise of "friendly flora" in the intestines, thus increasing the manufacture and absorption of all foods and strengthening the immune system to help fight off any type of disease [22].

Study limitations. The research needs additional study of water-soluble polysaccharides and pectin substances of the Agrimonia eupatoria L. herb in various phases of vegetation. For the statistical importance of the study, it would be expedient to investigate wild samples of raw materials from different regions of Ukraine.

Prospects for further research. According to the results of the studies, further screening of pharmacological studies, and development of parameters for standardization of Agrimonia eupatoria L. herb are planned.

\section{Conclusion}

In completion, the present results of GC/MS indicated the presence of certain carbohydrates both in free and bound form in Agrimonia eupatoria L., that have important medicinal activity, which answered to the knowledge about the therapeutic activity of this analyzed plant. Three free carbohydrates as D-glucose $(15.02 \mathrm{mg} / \mathrm{g})$, D-galactose $(0.28 \mathrm{mg} / \mathrm{g})$ and D-fructose $(12.90 \mathrm{mg} / \mathrm{g})$ were determined in the herb of raw material as the result of the experiment. D-rhamnose, L-arabinose, D-xylose, D-mannose, D-glucose, D-galactose, D-mannitol and DDulcitol, after acidic hydrolysis and derivatization with acetylated aldononitriles, were identified in the herb of Agrimonia eupatoria L. Among monosaccharides, after hydrolysis and free monosaccharides D-glucose was the predominant monosaccharide compound in the analyzed raw material. The amounts of water-soluble polysaccharides and pectin substances in the herb of Agrimonia eupatoria L. were determined by gravimetric method. The content of which was $2.90 \%$ and $8.54 \%$, respectively. Our findings propose that carbohydrates from the studied raw material can be used for creating medicine of the pharmaceutical industry, and could be used for the development of nutraceuticals.

\section{Conflict of interests} interest.

\section{References}

1. Slobodianiuk, L., Budniak, L., Marchyshyn, S., Sinichenko, A., Demydiak, O. (2021). Determination of Amino Acids of Cultivated Species of the Genus Primula L. Biointerface Research in Applied Chemistry, 11 (2), 8969-8977. doi: http://doi.org/10.33263/ briac112.89698977

2. Correia, H. S., Batista, M. T., Dinis, T. C. P. (2007). The activity of an extract and fraction ofAgrimonia eupatoriaL. against reactive species. BioFactors, 29 (2-3), 91-104. doi: http://doi.org/10.1002/biof.552029209

3. Kurennov, I. P. (2007). Zolotaia entsiklopediia narodnoi meditsiny. Moscow: Martin, 546. 
4. Hrytsyk, A. R., Tsveiuk, N. P., Leibenko, N. M., Sikoryn, U. B. (2004). Perspektyvni roslyny Karpatskoho rehionu z hepatoprotektornymy ta zhovchohinnymy vlastyvostiamy. Zaporozhskyi medytsynskyi zhurnal, 2 (1), 99-100.

5. Kuczmannová, A., Balažová, A., Račanská, E., Kameníková, M., Fialová, S., Majerník, J. et. al. (2016). Agrimonia eupatoria L. and Cynara cardunculus L. Water Infusions: Comparison of Anti-Diabetic Activities. Molecules, 21 (5), 564. doi: http://doi.org/10.3390/molecules21050564

6. Naprasnikova, H. S., Vladymyrova, I. M., Heorhiiants, V. A. (2011). Vyznachennia yakisnoho skladu fenolnykh spoluk Agrimonia eupatoria L. Aktualni pytannia stvorennia novykh likarskykh zasobiv. Kharkiv, 97.

7. Lee, K. Y., Hwang, L., Jeong, E. J., Kim, S. H., Kim, Y. C., Sung, S. H. (2010). Effect of Neuroprotective Flavonoids ofAgrimonia eupatoriaon Glutamate-Induced Oxidative Injury to HT22 Hippocampal Cells. Bioscience, Biotechnology, and Biochemistry, 74 (8), 1704-1706. doi: http://doi.org/10.1271/bbb.100200

8. Shabana, M. H., Weglarz, Z., Geszprych, A., Mansour, R. M., El-Ansari, M. A. (2003). Phenolic constituents of agrimony (Agrimonia eupatoria L.) herb. Herba polonica, 49 (1-2), 24-28

9. Kato, H., Li, W., Koike, M., Wang, Y., Koike, K. (2010). Phenolic glycosides from Agrimonia pilosa. Phytochemistry, 71 (16), 1925-1929. doi: http://doi.org/10.1016/j.phytochem.2010.08.007

10. Kozak, I. V., Vronska, L. V., Demyd, A. E., Hroshovyy T. A. (2017). Identification and quantitative determination of flavonoid in Agrimonia eupatoria. Pharmaceutical Review, 2, 38-46. doi: http://doi.org/10.11603/2312-0967.2017.2.7905

11. Khan, A. M., Alam, A., Nazamuddin, M. D. (2013). Agrimonia eupatoria Linn. A traditional herb and its scientific testimony - a review. American Journal of Pharmacy and Health Research, 1 (6), 25-36.

12. Husak, L., Dakhym, I., Marchyshyn, S., Nakonechna, S (2018). Determination of sugars and fructans content in Stachys sieboldii. International Journal of Green Pharmacy, 12, 70-74. doi: http://doi.org/10.22377/ijgp.v12i01.1527

13. Slobodianiuk, L., Budniak, L., Marchyshyn, S., Basaraba, R. (2019). Determination of amino acids and sugars content in Antennaria dioica Gaertn. International Journal of Applied Pharmaceutics, 11 (5), 39-43. doi: http://doi.org/10.22159/ ijap.2019v11i5.33909

14. Chen, Y., Xie, M. Y., Wang, Y. X., Nie, S. P., Li, C. (2009). Analysis of the monosaccharide composition of purified polysaccharides in Ganoderma atrum by capillary gas chromatography. Phytochemical analysis, 20 (6), 503-510. doi: http://doi.org/10.1002/pca.1153

15. Stoiko, L., Dakhym, I., Pokotylo, O., Marchyshyn, S. (2017). Polysaccharides in Centaurium erythraea Rafn. International Journal of Research in Ayurveda and Pharmacy, 2, 252-255. doi: http://doi.org/10.7897/2277-4343.082122

16. Kyslychenko, O. A., Koshovyi, O. M., Komisarenko, A. M. (2011). Aminokyslotnyi ta monotsukrovyi sklad kvitok Achilea millefolium Mill. Ukrainskyi medychnyi almanakh, 14 (2), 91-93.

17. Mergenthaler, P., Lindauer, U., Dienel, G. A., Meisel, A. (2013). Sugar for the brain: the role of glucose in physiological and pathological brain function. Trends in Neurosciences, 36 (10), 587-597. doi: http://doi.org/10.1016/j.tins.2013.07.001

18. Hayes, A. J., Melrose, J. (2018). Glycans and glycosaminoglycans in neurobiology: key regulators of neuronal cell function and fate. Biochemical Journal, 475 (15), 2511-2545. doi: http://doi.org/10.1042/bcj20180283

19. Sun, F. H., Cooper, S. B., Gui, Z. (2020). Effects of carbohydrate and protein co-ingestion during short-term moderate-intensity exercise on cognitive function. The Journal of Sports Medicine and Physical Fitness, 60(4). doi: http://doi.org/10.23736/s00224707.20.10322-0

20. Umbayev, B., Askarova, S., Almabayeva, A., Saliev, T., Masoud, A.-R., Bulanin, D. (2020). Galactose-Induced Skin Aging: The Role of Oxidative Stress. Oxidative Medicine and Cellular Longevity, 2020, 1-15. doi: http://doi.org/10.1155/2020/7145656

21. Chogtu, B., Arivazhahan, A., Kunder, S. K., Tilak, A., Sori, R., Tripathy, A. (2018). Evaluation of Acute and Chronic Effects of D-Galactose on Memory and Learning in Wistar Rats. Clinical Psychopharmacology and Neuroscience, 16 (2), $153-160$. doi: http://doi.org/10.9758/cpn.2018.16.2.153

22. Pfützner, A., Demircik, F., Sachsenheimer, D., Spatz, J., Pfützner, A. H., \& Ramljak, S. (2016). Impact of Xylose on Glucose-Dehydrogenase-Based Blood Glucose Meters for Patient Self-Testing. Journal of Diabetes Science and Technology, 11 (3), 577-583. doi: http://doi.org/10.1177/1932296816678428

Received date 16.11.2020

Accepted date 22.12.2020

Published date 30.12.2020

Natalia Huzio, Assistant, Department of Pharmacy, Ivano-Frankivsk National Medical University, Halytska str., 2, Ivano-Frankivsk, Ukraine, 76018,

E-mail: nataliiahuzo@gmail.com

Andriy Hrytsyk, Doctor of Pharmaceutical Sciences, Professor, Department of Pharmacy, Ivano-Frankivsk National Medical University, Halytska str., 2, Ivano-Frankivsk, Ukraine, 76018

E-mail: grycyk@ukr.net

Liudmyla Slobodianiuk, PhD, Assistant Professor, Department of Pharmacognosy and Medical Botany, I. Horbachevsky Ternopil National Medical University of Ministry of Health of Ukraine, Voli ave., 1, Ternopil, Ukraine, 46001

E-mail: lydahusak29@gmail.com 